\title{
Education of Older People for Combating Their Loneliness
}

\author{
Jana Goriup - Branka Čagran - Katja Krošl"
}

\begin{abstract}
The article discusses education of older people for combating their loneliness, the reasons for it, and its consequences. The current theoretical findings were the reason for the empirical study of the research problem by the authors. In the empirical part, some aspects of the life of older people regarding their residences were compared: among older people living with their relatives, alone, with a partner, or in a retirement home, with special regard to the reasons/causes for residence, and the feeling of loneliness and contacts with relatives. The obtained empirical results showed that older people living alone or in a retirement home are in a worse position compared to those living with relatives or with a partner. The most at risk are older people living alone.
\end{abstract}

Key words: education, older people, residence type, reasons/causes for residence, loneliness, contacts.

\section{Introduction}

The meanings of age are not unchangeable. They respond to the pressures of each new cohort through the everyday interactions of cohort members, the millions of apparently unrelated individual decisions, the gradually emerging cohort definitions which then merge into new or altered norms, contracts, laws, social institutions. The meaning of age and aging is under constant social pressure, it is the subject of constant redefinition in which each individual plays an active part (Riley, 1978, p. 50).

In the past, people had a favourable attitude towards age. Older people were valued due to their experience, and only in rare cases were they unwanted because of their impaired physical functions. Older people with a high social status were especially valued since they had social power and as the owners of material assets also the power to make decisions. Older people enjoyed great respect, and aging represented a popular and fully extended symbol of the fate of human life. In the 1960s, the perception of age completely changed since both age and aging became the subject of social institutionalizing. Intensive

\footnotetext{
* Jana Goriup, University of Maribor, Slovenia; jana.goriup@um.si Branka Čagran, University of Maribor, Slovenia; branka.cagran@um.si Katja Krošl, University of Maribor, Slovenia; katja.krosl@gmail.com
} 


\section{Acta Technologica Dubnicae \\ volume 5, 2015, issue 1}

demographic changes in the developed postmodern societies and the increase of the heterogeneity of the older population pushed older people to the margins of society, and defined their status of a dependent social category by implementing the institutionalization act. Based on its theory of a risk society, Beck established that the transition into the industrial society caused the formation of a productivity-oriented society which in accordance with its own interests, creates an image of older people as dependent, unproductive, and inactive members of society. The prevalent stereotypes about age in society create the general negative attitude towards age and affect the experience of age in older people which consequently results in their low self-esteem. Their expectations and demands become low as well (Beck, 2001).

Despite numerous improvements regarding the integration of older people into society, many of them still encounter gerontophobia, age segregation, marginalization, and social stigma. And as a consequence, loneliness! Those factors promote their helplessness and dependence, extensively affecting social inclusion or exclusion of the older population. Acts of institutionalizing are in their basis the product of the social construction, contributing to the legitimacy, loneliness, and social distance among older people. Although the share of the older population is growing intensively and leads into the unavoidable demographic aging, the cultural and social meaning of aging are changing very slowly in Slovene society, also due to myths about aging. White Riley (1978) states three main fallacies (re)producing the myths about aging:

- life-course fallacy which is evident from cross-section data in which old people have lower educational attainment than young people. The apparent decline occurs because the more recent cohorts are better educated than their predecessors;

- fallacy of age reification in which chronological age itself is treated as if it were a causal factor. Yet particular years of age have no meaning in themselves; they are mere indexes, useful only as they reflect socially or theoretically relevant components of personal or social change; and

- fallacy of overgeneralizing from the experience of a single cohort (cohortcentrism) as Robert Merton puts it, "Structure constrains individuals variously situated within it to develop cultural emphases, social behaviour patterns and psychological bents." Thus, any personal biography of a member of a cohort can only emphasize the constraints imposed by social structure and social change. Thus one generation's "common sense" about aging may no longer make sense to a later generation. The universal theory of aging should be an abstraction of experience as each new cohort confronts a different set of social and environmental events (Riley, 1978, p. 44). 


\section{Acta Technologica Dubnicae \\ volume 5, 2015, issue 1}

\section{Aging}

Even though aging is a development process of each individual and can have an individual or social character, we must distinguish between the process of aging and the concept of age. According to Kolland (1993, p. 537), aging can be defined as the process of change and development through the entire life-course while age is a state of an individual in which his identity is being newly created. According to Ramovš (2003, p. 69), the concept of age can be differentiated on the basis of chronological age indicated by the birth date; functional age which is evident into what extent a person is able to independently do his everyday chores and how healthy he is (referred to as "biological age" by doctors), and perceptual age. Perceptual age is evident in a person's embrace and perception of his current age; it is more complex in its nature and refers to the human relation towards age.

As Williams (1957) and Finch (1990), De Magalhaes (2012) uses the term "senescence" instead of "aging" as well since he wants to emphasize aging as an active genetically controlled process. The use of the term senescence encompasses the presumption that the aging process is at the mercy of the operation of human cells. While human cells are basic structural units of our bodies, it is logical to presuppose to some extent that changes at the cellular level affect the body, the person and their aging process. However, we emphasize that such conception stresses only a specific aspect of the aging process since human cells are not the only factor affecting the aging process. The majority of experts agree that the aging process is the result of various effects on the body - environmental, genetic, cultural, nutritional, and physical. Aging is a process of biological, psychological and social changes which among other things have an important effect on shaping one's personality.

Thus aging is a phenomenon with personal and social implications. "For an individual, it is a process of physical, mental and psychological change through the entire life-course. For society itself, however, an aging population has several social, economic, cultural, ethnic and political dimensions." (Kersnik Bergant, 1999, p. 95)

Aging can also be understood as "a universal process which happens due to the interaction between a genome and its environment" (Cijan and Cijan, 2003, p. 22 ) and as "a constant process leading to the loss of the body's ability to adapt, a decline in the intensity of life functions and a more and more gradual, however unavoidable loss of the functional ability. Age is therefore an anteroom to death, the same as childhood is an anteroom to life." (Cijan and Cijan, 2003, p. 23)

Social theories of aging establish that the relation between a person and its social environment is especially important. Well-being in one's old age thus depends mostly on the expectations in the environment in which he lives. It is difficult to exactly specify the limit to call someone old. The World Health Organization set the limit at 60 years since they believe old age comes after 60 years of age (Cijan and Cijan, 2003, p. 22). In the developed world, aging begins after the age 


\section{Acta Technologica Dubnicae \\ volume 5, 2015, issue 1}

of 65 . With a higher life expectancy, the third age began to divide into the fourth age. The third age lasts from retirement to 75 years of age, and the fourth from 75 years onwards (Kersnik Bergant, 1999, p. 95).

Under modern conditions, old age is becoming a problem after the age of 75 since only then many old people are not able to take care of themselves any more. They become dependent on other people. (Cijan and Cijan, 2003, p. 22). Old age can be divided into three brackets. First, the early age bracket lasts from the age of 66 to 75 . For this bracket, it is characteristic that a person is adapting to a retirement way of life. Then, the middle age bracket follows which lasts from the age of 76 to 85 . Old people in this bracket deal with health problems, their physical power is declining, their peers are dying, a lot of them have already become widows or widowers. The final phase is the late age bracket after the age of 86. Old people receive the help of others since they are no longer able to take care of themselves (Ramovš, 2003, pp. 74-75). In Slovenia, the "younger" and "older" groups were identified based on their physical, psychological and material characteristics (Accetto et al., 1987; adapt. from Hojnik Zupanc, 1999, p. 104). The younger group is limited by chronological age from $60(65)$ to 75 (80) years. The characteristics of the younger generations are: physical and mental vitality, decreased activity, the members are identified as pensioners, they have a better socioeconomic status in comparison to the older group, a consumer way of life, they think of retirement homes as the best solution for helpless old people, etc. (Hojnik Zupanc, pp. 104-105). The older group is limited by chronological age of 75 years or more. Characteristics of the older group are: more health problems, decreased physical activity, they often live alone, many of them are without a partner, poor socioeconomic status, limited material needs, low life demands, etc. (Hojnik Zupanc, p. 105).

With a higher life expectancy, old people encounter problems due to the fact that they are no longer able to fulfil their own needs (Svažič, 1994, p. 88). 
Table 1: Older people and the accomplishment of assignments

\begin{tabular}{l|l|l|}
\cline { 2 - 3 } & Late Adulthood (65-75) & $\begin{array}{l}\text { Late, Late } \\
\text { Adulthood (75+) }\end{array}$ \\
\hline Physical Changes & $\begin{array}{l}\text { Noticeable decline in physical } \\
\text { power; longer reaction time }\end{array}$ & $\begin{array}{l}\text { Faster decline in } \\
\text { physical and health } \\
\text { functions }\end{array}$ \\
\hline Cognitive Changes & $\begin{array}{l}\text { Slow decline in various } \\
\text { abilities }\end{array}$ & $\begin{array}{l}\text { Faster decline in } \\
\text { cognitive abilities, } \\
\text { mostly memory }\end{array}$ \\
\hline Family and & $\begin{array}{l}\text { Grandparents; less important } \\
\text { family roles }\end{array}$ & $\begin{array}{l}\text { Family roles } \\
\text { relatively } \\
\text { unimportant }\end{array}$ \\
\hline Relationships & $\begin{array}{l}\text { Great satisfaction in marriage } \\
\text { (if not widows or widowers); } \\
\text { intimate friendship; frequent } \\
\text { contacts with children }\end{array}$ & $\begin{array}{l}\text { Most of them are } \\
\text { widows or } \\
\text { widowers; friends } \\
\text { remain important }\end{array}$ \\
\hline Work Roles & Retirement (for the majority) & $\begin{array}{l}\text { Unimportant (for } \\
\text { the majority) }\end{array}$ \\
\hline $\begin{array}{l}\text { Personality and } \\
\text { Personal Meaning }\end{array}$ & $\begin{array}{l}\text { Integrity of the ego (goal); } \\
\text { introversion; some of them } \\
\text { reach the level of integrity }\end{array}$ & $\begin{array}{l}\text { Previous processes } \\
\text { continue }\end{array}$ \\
\hline Key Assignments & $\begin{array}{l}\text { Facing retirement and the } \\
\text { decline in physical and mental } \\
\text { functions; redefining of life } \\
\text { goals and personal meaning }\end{array}$ & $\begin{array}{l}\text { Facing the end of } \\
\text { life and the } \\
\text { possibility of } \\
\text { illness and } \\
\text { worsened ability }\end{array}$ \\
\cline { 2 - 3 } & \multicolumn{2}{|l}{}
\end{tabular}

Source: Bee (1996, pp. 388-389), Kump and Jelenc Krašovec (2009, p. 17), Bee (1996). The journey of adulthood. Upper Saddle River: Prentice Hall.

Based on age, some social gerontologists distinguish between the third and fourth age. Characteristic for this segment is the assignment in the third age to deliver one's life understandings and experience directly to fellow people and indirectly to the culture. In the third age, old people are still full of life energy and the thought of death is not yet constantly present. Most of this population still enjoys almost complete autonomy of their lives and creativity in the chosen activities they find enjoyable and are capable of doing them. In his conceptualization of age, Laslett (1989) specifically distinguishes the fourth age and connects it with dependency, helplessness, illness and death. Although he warns that this period often does not even happen or is very short. 


\section{Acta Technologica Dubnicae \\ volume 5, 2015, issue 1}

Sometimes we are surprised when a person says how old he is. It is not uncommon that with their external appearance, people show fewer years than they actually have. It can be distinguished among three types of old age: chronological age which can be defined as age apparent according to the calendar, biological age which can be defined as the age of the body and psychological age which is one's perception of his age, how old he feels (Hojnik Zupanc, 1997, pp. 3-4). Trstenjak (1985) measured age with the "index of cicatrization" i.e. the speed of superficial wound healing. A five-year-old takes 6 days to heal certain wounds while a sixty-year-old takes 42 days. The essence of aging is in the aging of cells which are becoming ever slower, less adaptable and have an impaired healing ability; tissue hydration is worsened, as well as the basic metabolism which is the cause for the process of sedimentation in cells (Trstenjak, 1985, p. 403).

\section{Loneliness}

For the majority of old people, it is also difficult to face the fact that they are old because of the prevailing stereotypes in society. Instead of confronting such stereotyping, they would rather live the lifestyle of the young as long as they can. When their health and physical functioning worsen, their standard of living and cognitive abilities decline, their appearance changes and they experience social loss, and "loneliness" comes into the life of older people.

Loneliness is one of the worst afflictions of old age. Old people who are lonely also start to perceive their full past life as something empty and unworthy. For an old person, loneliness is as bad as physical malnutrition. It is a hunger for the closeness of someone who is close to them (Ramovš, 2003, p. 104). Loneliness is an emotional state in which a person feels strong feelings of emptiness and isolation; it is more than just a need for the company of a fellow man. It is a feeling of being estranged and isolated from people (Hvalič Touzery, 2006, p. $55)$. Older people can thus experience social or emotional loneliness, or both. Social isolation is a result of the isolation by society and the inability of an old person to socially integrate. Emotional isolation, however, is the result of the loss of a partner, family, friends, lack of social contacts (Luanaigh and Lawlor, 2008, p. 1213-21). A lower socioeconomic status can increase gerontophobia due to the fear of the inability to support oneself and pay for health care (Lynch, 2000, p. 537).

If one's need for relationships is not satisfied, one is lonely (Ramovš, 2003, p. 211). However, there is no rule for this. A person living alone does not necessarily feel lonely. He can feel good and has no problems making new contacts with people. On the other hand, someone can live surrounded by a lot of people, for example in a retirement home or hospital, and experience loneliness. One is not able to make contact with people (Ramovš, 2003, pp. 211-212). Therefore, the feeling of loneliness is not directly related to the frequency of contacts with other people. One can feel lonely also when one is surrounded by a 


\section{Acta Technologica Dubnicae \\ volume 5, 2015, issue 1}

crowd of people. At the same time, some people have little contact with others and they do not feel lonely. The causes of loneliness in old age can be various: the death of a spouse, relative, illness, children moving away, etc. A partner is supposed to be the best cure for loneliness, followed by children (Požarnik, 1981, pp. 134-135).

The feeling of loneliness also depends on one's expectations. An older person expecting his children will visit him once a day is going to feel lonely if there are no visits for a few days. Also, ill people are lonelier than those who are healthy since they cannot entertain themselves. Illness and loneliness are related. On one side, illness causes loneliness. On the other side, loneliness causes worse physical and emotional well-being (Požarnik, 1981, p. 137).

There is a common belief that we always need people in our lives. When a person is born he needs another person to perform life functions, such as feeding. The need for a personal relationship is very important in old age as well. We could say it is the main need in the third age which is, however, often unsatisfied (Ramovš, 2003, pp. 103-104). An old person needs regular personal contact with someone he trusts. In traditional society, this person would be a blood relative. Nowadays this is different since traditional societies are largely losing their meaning and relatives are being replaced by people who are in that old person's life through his choice. Yet, it is definitely not unimportant who is next to an old person. That can be a large group of people but if there is not the "right" person among them he is lonely. Loneliness can be seen in people living in retirement homes or hospitals.

Old people are nursed by a lot of experts, care assistants and serving attendants satisfying their physical needs. Sadly, this is where it ends. For them they are people which they cannot depend on in times of distress (Ramovš, 2003, pp. 103-104). A critical period in old age is widowhood because it is then when an older person is left alone. He feels lonely because there is nobody next to him. His living space becomes too much for him (Hojnik Zupanc, 1999, p. 61). Older people are many times also excluded from groups. The result is loneliness. They are excluded due to their life situation, children moving away, retirement which excludes them from the work unit. However, all this can be avoided by children maintaining contact with their parents, by older people taking up additional and voluntary work when retired, etc. (Pečjak, 2007, pp. 76-77).

With older people, loneliness can be compared to physical malnutrition since they are equally important to them. The consequences are similar. In both cases, an old person can become ill in time (Ramovš, 2003, pp. 103-104). In case the feeling of loneliness is predominant over other feelings, we can talk about a social disorder. The only solution preventing the spreading of loneliness into a worse social disorder is a personal human relationship (Ramovš, pp. 421-422).

It is well worth stressing that people all around the developed world are as lonely today as never before in the entire human history. High material standards on the one hand and low mental, spiritual and interpersonal standards on the 


\section{Acta Technologica Dubnicae \\ volume 5, 2015, issue 1}

other lead to the low quality of life of today's older people (Ramovš, 2003, p. 327). The only solution to prevent the spread of loneliness into a worse social disorder is personal human relationships (Ramovš, 2003, pp. 421-422). A preventive asset for loneliness is also the telephone. Old people communicate with their friends and relatives over the phone and thus reduce their loneliness (Hojnik Zupanc, 1999, pp. 153-154). This is especially important if they are ill. The phone is also an asset through which older people can inform others if they need anything, if something happened to them etc. (Požarnik, 1981, p. 138). Numerous sociological factors like cohort, ethnicity, social class, level of education, sex, etc. can affect our perception and understanding of aging. All those factors affect one's accessibility to economic status, knowledge and different experiences related to aging. They enrich or increase assets with which one can confront bad health, wrinkles and other signs of aging. As a result, those factors could contribute to adecreased fear of aging and older people, and also to decreased gerontophobia as a complex phenomena.

\section{THE PURPOSE OF THE STUDY}

The purpose of our study was to compare old people living with their relatives, alone, with a partner or in a retirement home. We focused on:

- reasons for their residence;

- feeling of loneliness, contacts with relatives.

We were interested in the effect of the manner of residence on loneliness in older people or which group of older people is the most at risk according to the residence type from the mentioned aspects.

\section{METHODOLOGY}

\section{Research sample}

The study was based on a non-random (convenience) sample of old people in the northeastern Slovenian region (Dravsko-Ptujsko polje). At the level of inferential statistics, the sample is defined as a simple random sample of a hypothetical population.

The sample included 75 males (34.1\%) and 145 females (65.9\%). The sample included more females than males which is not surprising since in 2012, the average female life expectancy in Slovenia was 80 years and 71.8 years for males (Statistical Office of the RS, 2013). This is an indication that on average, women live 8.2 years longer than men and as a result, outnumber them. The information about premature mortality shows that in 2012, almost every third male and every eighth female died younger than 65 years old. This is also proof that on average, men die younger than women (Statistical Office of the RS, 2013).

The majority of old people included in our sample were between 60 and 70 years old $(46.4 \%)$, followed by those 80 years old $(33.2 \%)$. The minority were 


\section{Acta Technologica Dubnicae \\ volume 5, 2015, issue 1}

represented by old people under 60 and over 80 years old. As an interesting fact we can add that the age dispersion ranged from 58 to 92 years. The condition for the participation was retirement.

In Slovenia, the right to age-related retirement depends on different factors, namely on reaching a certain age and a long enough retirement-insurance period without the possibility of an additional purchase. Both conditions must be met. A female must be 58 years old and have 38 years and 4 months of years of service without an additional purchase to retire, a male 58 years and 4 months old with 40 years of service without an additional purchase. The right to the agerelated retirement can in some cases be adapted. For females, the age can be lowered to 56 years, for men to 58 years (Institute for Pension and Disability Insurance of Slovenia, 2013). As a criterion for our study, we considered the minimum age of 58 years. This is the age at which it is possible to reach retirement following the normal procedure without any cuts. Therefore, the youngest older person participating in our study was 58 years old.

Most of the old people had a high-school diploma (46.8\%), followed by those who finished primary school (39.1\%). A small percentage of interviewees did not finish primary school (4.1\%), some of them had a Bachelor's degree $(2.7 \%)$ and a Master's degree or $\mathrm{PhD}(0.95)$.

As the main criterion for establishing whether old people are endangered, our assignment was to discuss residence types. According to them, the sample included 70 people (31.8\%) living with their relatives, 40 people (18.2\%) living alone, 50 people $(22.7 \%)$ living in a retirement home and 60 people $(27.3 \%)$ living with their partner. Among the cohorts of old people, the percentages are not the same according to residence type. This is a result of residence types which are well established in practice (for example: most of the older people live with their relatives).

\section{Data collecting procedure}

The data was collected from March until May 2013 at primary schools (city and suburban schools) and retirement homes in the Dravsko-Ptujsko polje region. At the primary schools, questionnaires were given to the headmasters, pedagogical workers, social workers and teachers who gave them to their students. They then forwarded them to the retired people and returned them to their teachers after they had been filled in. In retirement homes, inmates filled in the questionnaire alone or with our help or with the help of social workers (in the case of medical obstacles).

\section{Contents and methodological characteristics of the questionnaire}

The questionnaire was composed of 17 closed-ended questions and two sets of scales (contentment, values).

The questionnaire provided measuring characteristics, namely: 


\section{Acta Technologica Dubnicae \\ volume 5, 2015, issue 1}

The validity of the questionnaire was based on the probe use. It showed that questions were well formed; corrections were unnecessary.

Reliability was provided with precise instructions and specific questions. The reliability of the evaluation scales was tested with Cronbach's alpha coefficient. The value $\alpha=0.778$ indicates that the scales (contentment, values) in the questionnaire are reliable enough.

Objectivity was provided with closed-ended questions, data collecting which was individual, unguided and guided. Guided data collecting only included reading the questions. In the phase of reading nothing was changed which means there was no subjective influence.

\section{Data processing procedures}

The data was processed using the SPSS. A frequency distributions (f, f \%) and $\chi^{2}$ - the test (Che-Square Test) was used because the frequency of non-numeric variables (nominal, ordinal) was analyzed.

\section{RESULTS REVIEW AND INTERPRETATION}

Analysis of reasons for residence

Old people could choose among the suggested reasons.

Table 2: The number (f) and percentage (f \%) of older people according to reasons for residence

\begin{tabular}{|c|c|c|}
\hline $\begin{array}{c}\text { Reasons/causes for } \\
\text { residence }\end{array}$ & $\mathrm{f}$ & $\mathrm{f} \%$ \\
\hline Health conditions & 55 & 25.0 \\
\hline $\begin{array}{c}\text { Poor relations with } \\
\text { relatives }\end{array}$ & 7 & 3.2 \\
\hline Financial conditions & 10 & 4.5 \\
\hline Loneliness & 14 & 6.4 \\
\hline Dependence & 7 & 3.2 \\
\hline $\begin{array}{c}\text { Feeling of being a } \\
\text { burden to relatives }\end{array}$ & 6 & 2.7 \\
\hline Other & 121 & 55.0 \\
\hline Total & 220 & 100.0 \\
\hline
\end{tabular}

It is evident from the table that the majority (55\%) of older people stated "Other" as the reason/cause for residence. Their answers are written in the interpretation of the Table 3 since they apply to a specific cohort of older people according to residence type. The second most common answer was "Health conditions" (25\%). Other answers (Poor relations with relatives, Financial conditions, Loneliness, Dependence and the Feeling of being a burden to relatives) appeared in lower percentages. 
Table 3: The number (f) and percentage (f \%) of older people according to reasons for residence according to certain residence type

\begin{tabular}{|c|c|c|c|c|c|c|c|c|c|c|}
\hline $\begin{array}{r}\text { Residence } \\
\text { type }\end{array}$ & \multicolumn{2}{|c|}{$\begin{array}{c}\text { With } \\
\text { relatives }\end{array}$} & \multicolumn{2}{|c|}{ Alone } & \multicolumn{2}{c|}{$\begin{array}{c}\text { In a } \\
\text { retirement } \\
\text { home }\end{array}$} & \multicolumn{2}{|c|}{$\begin{array}{c}\text { With a } \\
\text { partner }\end{array}$} & \multicolumn{2}{|c|}{ Total } \\
\cline { 2 - 11 } & $\mathrm{f}$ & $\mathrm{f} \%$ & $\mathrm{f}$ & $\mathrm{f} \%$ & $\mathrm{f}$ & $\mathrm{f} \%$ & $\mathrm{f}$ & $\mathrm{f} \%$ & $\mathrm{f}$ & $\mathrm{f} \%$ \\
\hline $\begin{array}{c}\text { Health } \\
\text { conditions }\end{array}$ & 11 & 15.7 & 3 & 7.5 & 35 & 70.0 & 6 & 10.0 & 55 & 25.0 \\
\hline $\begin{array}{c}\text { Poor } \\
\text { relations } \\
\text { with } \\
\text { relatives }\end{array}$ & 2 & 2.9 & 4 & 10.0 & 1 & 2.0 & 0 & 0.0 & 7 & 3.2 \\
\hline $\begin{array}{c}\text { Financial } \\
\text { conditions }\end{array}$ & 6 & 8.6 & 0 & 0.0 & 0 & 0.0 & 4 & 6.7 & 10 & 4.5 \\
\hline Loneliness & 5 & 7.1 & 0 & 0.0 & 6 & 12.0 & 3 & 5.0 & 14 & 6.4 \\
\hline Dependence & 2 & 2.9 & 0 & 0.0 & 4 & 8.0 & 1 & 1.7 & 7 & 3.2 \\
\hline $\begin{array}{c}\text { Feeling of } \\
\text { being a } \\
\text { burden to } \\
\text { relatives }\end{array}$ & 0 & 0.0 & 4 & 10.0 & 0 & 0.0 & 2 & 3.3 & 6 & 2.7 \\
\hline Other & 44 & 62.9 & 29 & 72.5 & 4 & 8.0 & 44 & 73.3 & 121 & 55.0 \\
\hline Total & 70 & 100.0 & 40 & 100.0 & 50 & 100.0 & 60 & 100.0 & 220 & 100.0 \\
\hline
\end{tabular}

Result of the $\chi^{2}$-test: $\chi^{2}=116.924, \mathrm{~g}=18, \alpha(\mathrm{P})=0.000$

As the result of the $\chi^{2}$-test shows, there is a statistically significant difference in reasons for residence according to certain type of residence. Old people living in a retirement home stand out. They stated "Health conditions" $(70.0 \%)$ as the main reason for their residence. In all other cohorts, health reasons were represented in much lower percentages. Old people living with their relatives, alone or with their partner most commonly chose the answer "Other" and also wrote down their answer. The answers were very different. As the reason for their residence, old people living with relatives wrote "family house", "fewer responsibilities because of the distribution of chores", "babysitting grandchildren", "I like it this way", "we get along very well", "we agreed". The most common answers of old people living alone were: "independence", "divorce", "one's own master", "it is my home, I don't want to leave it". Answers of old people living with their partner were: "I like it this way", "our own house", "it's normal", "I am married", "love". The answers tell us that the reasons/causes for an old person's residence according to certain type of residence are very different. We could sum up that the majority of old people live in a retirement home due to their health problems and need for care. In 
cohorts living with relatives, alone or with a partner it is difficult to stress one reason since the answers were so different.

\section{Analysis of loneliness and contacts}

Old people evaluated their loneliness and experience with human contacts.

Table 4: The number (f) and percentages (f \%) of old people according to loneliness

\begin{tabular}{|c|c|c|}
\hline Answer & f & f \% \\
\hline Never & 114 & 51.8 \\
\hline Rarely & 85 & 38.6 \\
\hline Often & 21 & 9.5 \\
\hline Total & 220 & 100.0 \\
\hline
\end{tabular}

Based on the acquired empirical data, we established that most old people chose the answer "Never" (51.8\%) for the question about their loneliness, followed by "Rarely" (38.6\%) and "Often" (9.5\%). According to the results, we can conclude that the feeling of loneliness is not common in old people.

Table 5: The number (f) and structural percentages (f \%) of old people according to loneliness according to certain residence type

\begin{tabular}{|c|c|c|c|c|c|c|c|c|c|c|}
\hline \multirow{2}{*}{$\begin{array}{c}\text { Residence } \\
\text { type }\end{array}$} & \multicolumn{2}{|c|}{$\begin{array}{c}\text { With } \\
\text { relatives }\end{array}$} & \multicolumn{2}{|c|}{ Alone } & \multicolumn{2}{c|}{$\begin{array}{c}\text { In a } \\
\text { retirement } \\
\text { home }\end{array}$} & \multicolumn{2}{c|}{$\begin{array}{c}\text { With a } \\
\text { partner }\end{array}$} & \multicolumn{2}{|c|}{ Total } \\
\cline { 2 - 12 } Answer & f & f \% & f & f \% & f & f $\%$ & f & f \% & f & f \% \\
\hline Never & 45 & 64.3 & 10 & 25.0 & 20 & 40.0 & 39 & 65.0 & 114 & 51.8 \\
\hline Rarely & 23 & 32.9 & 21 & 52.5 & 22 & 44.0 & 19 & 31.7 & 85 & 38.6 \\
\hline Often & 2 & 2.9 & 9 & 22.5 & 8 & 16.0 & 2 & 3.3 & 21 & 9.5 \\
\hline Total & 70 & 100.0 & 40 & 100.0 & 50 & 100.0 & 60 & 100.0 & 220 & 100.0 \\
\hline
\end{tabular}

Result of the $\chi^{2}$ - test: $\chi^{2}=29.654, g=6, \alpha(P)=0.000$

As the result of the $\chi^{2}$-test shows, there is a statistically significant difference in the question related to loneliness of old people according to certain residence types. The answer "Never" was chosen by the majority of old people living with their relatives $(64.3 \%)$ and partner $(65.0 \%)$. The answer "Rarely" was chosen mostly by old people living alone $(52.5 \%)$ and in a retirement home $(44.0 \%)$. The answer "Often" was more frequently chosen by old people living alone $(22.5 \%)$ and in a retirement home (16\%) than by those living with relatives $(2.9 \%)$ or a partner $(3.3 \%)$. The results show that old people who have no relatives next to them, those living alone or in a retirement home, are more often lonely. We could conclude that family plays an important role in overcoming loneliness. 


\section{Acta Technologica Dubnicae \\ volume 5, 2015, issue 1}

If we sum up, the most lonely and thus the most endangered are old people living alone.

Table 6: The number (f) and percentages (f \%) of old people according to the frequency of contacts with relatives

\begin{tabular}{|c|c|c|c|c|c|c|}
\hline \multirow{2}{*}{ Contacts } & \multicolumn{2}{|c|}{$\begin{array}{c}\text { Over the } \\
\text { phone }\end{array}$} & \multicolumn{2}{c|}{ Visits } & \multicolumn{2}{c|}{ During holidays } \\
\cline { 2 - 7 } Answer & $\mathrm{f}$ & $\mathrm{f} \%$ & $\mathrm{f}$ & $\mathrm{f} \%$ & $\mathrm{f}$ & $\mathrm{f} \%$ \\
\hline Never & 11 & 5.0 & 2 & 0.9 & 3 & 1.4 \\
\hline Rarely & 59 & 26.8 & 61 & 27.7 & 34 & 15.5 \\
\hline Often & 150 & 68.2 & 155 & 71.4 & 183 & 83.2 \\
\hline Total & 220 & 100.0 & 220 & 100.0 & 220 & 100.0 \\
\hline
\end{tabular}

The results showed that old people have the most frequent contacts with their relatives during holidays $(83.2 \%)$, followed by visits $(71.4 \%)$ and telephone conversations $(68.2 \%)$.

Table 7: The number (f) and percentages (f \%) of old people according to the frequency of contacts with relatives according to certain residence type

\begin{tabular}{|c|c|c|c|c|c|c|c|c|}
\hline Cont & Reside & type & $\begin{array}{l}\text { With } \\
\text { relatives }\end{array}$ & Alone & $\begin{array}{c}\text { In a } \\
\text { retirement } \\
\text { home }\end{array}$ & $\begin{array}{l}\text { With a } \\
\text { partner }\end{array}$ & $\chi^{2}$ & $\mathrm{P}$ \\
\hline \multirow{2}{*}{$\begin{array}{l}\stackrel{0}{ \pm} \\
\stackrel{0}{0} \\
\stackrel{0}{0}\end{array}$} & $\begin{array}{l}\text { Never, } \\
\text { rarely }\end{array}$ & $\begin{array}{l}\mathrm{f} \\
\mathrm{f} \%\end{array}$ & $\begin{array}{c}21 \\
30.0\end{array}$ & $\begin{array}{c}10 \\
25.0\end{array}$ & $\begin{array}{c}29 \\
58.0\end{array}$ & $\begin{array}{c}10 \\
16.7\end{array}$ & \multirow{2}{*}{$\begin{array}{l}23 . \\
112\end{array}$} & \multirow{2}{*}{0.000} \\
\hline & Often & $\begin{array}{l}\mathrm{f} \\
\mathrm{f} \%\end{array}$ & $\begin{array}{c}49 \\
70.0\end{array}$ & $\begin{array}{c}30 \\
75.0\end{array}$ & $\begin{array}{c}21 \\
42.0\end{array}$ & $\begin{array}{c}50 \\
83.3\end{array}$ & & \\
\hline \multirow{2}{*}{ 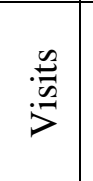 } & $\begin{array}{l}\text { Never, } \\
\text { rarely }\end{array}$ & $\begin{array}{l}\mathrm{f} \\
\mathrm{f} \%\end{array}$ & $\begin{array}{c}10 \\
14.3\end{array}$ & $\begin{array}{c}20 \\
50.0\end{array}$ & $\begin{array}{c}25 \\
50.0\end{array}$ & $\begin{array}{c}8 \\
13.3\end{array}$ & \multirow{2}{*}{$\begin{array}{c}34 . \\
030\end{array}$} & \multirow{2}{*}{0.000} \\
\hline & Often & $\begin{array}{l}\mathrm{f} \\
\mathrm{f} \%\end{array}$ & $\begin{array}{c}60 \\
85.7\end{array}$ & $\begin{array}{c}20 \\
50.5\end{array}$ & $\begin{array}{c}25 \\
50.5\end{array}$ & $\begin{array}{c}52 \\
86.7\end{array}$ & & \\
\hline \multirow{2}{*}{ 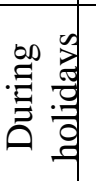 } & $\begin{array}{l}\text { Never, } \\
\text { rarely }\end{array}$ & $\begin{array}{l}\mathrm{f} \\
\mathrm{f} \%\end{array}$ & $\begin{array}{c}9 \\
12.9\end{array}$ & $\begin{array}{c}4 \\
10.0\end{array}$ & $\begin{array}{c}22 \\
44.0\end{array}$ & $\begin{array}{c}2 \\
3.3\end{array}$ & \multirow[b]{2}{*}{$\begin{array}{c}36 . \\
320\end{array}$} & \multirow[b]{2}{*}{0.000} \\
\hline & & $\begin{array}{l}\mathrm{f} \\
\mathrm{f} \%\end{array}$ & $\begin{array}{c}61 \\
87.1\end{array}$ & $\begin{array}{c}36 \\
90.0\end{array}$ & $\begin{array}{c}28 \\
56.0\end{array}$ & $\begin{array}{c}58 \\
96.7\end{array}$ & & \\
\hline
\end{tabular}

Note: The answers "Never" and "Rarely" were combined due to low frequencies.

The results of the $\chi^{2}$-test showed that the difference in all three forms of old people's contact with their relatives (over the phone, visits and during holidays) is statistically significant. In the form "Over the phone" $\left(\chi^{2}=23.112, \mathrm{P}=0.000\right)$, 


\section{Acta Technologica Dubnicae \\ volume 5, 2015, issue 1}

old people living in a retirement home stand out since they most frequently chose the answer "Never/rarely" (58.0\%). The answer "Often" was most frequently given by old people living with their relatives $(70.0 \%)$, alone $(75.0 \%)$ and a partner $(83.3 \%)$. Contacts with their relatives through visits $\left(\chi^{2}=34.030\right.$, $\mathrm{P}=0.000)$ are more frequent for old people living with their relatives $(85.7 \%)$ and partner $(86.7 \%)$ than for those living alone or in a retirement home. Contacts during holidays $\left(\chi^{2}=36.320, \mathrm{P}=0.000\right)$ are the least frequent for old people living in a retirement home, much more for those living with their relatives $(87.1 \%)$, alone $(90 \%)$ or with a partner $(96.7 \%)$.

To sum up, the most at risk old people are the ones living in a retirement home since they have the least contact with their relatives, which consequently brings a more common feeling of loneliness.

\section{Conclusions}

In times of modernization, wisdom or experience lost its meaning. It has become more and more irrelevant factor in gaining access and control over socially important resources. As a result, this led to a diminished authority and devaluation of the meaning of an old person status and their loneliness. Simmons emphasizes that the society's modernization caused the loss of the political and social power as well as influence and control once in the hands of old people. The side effect is social, moral and intellectual generation segregation. And consequently loneliness (Hoyman and Asuman, 2009, p. 48).

The results have been presented of an empirical study conducted on a sample of pensioners living in northeastern Slovenia. They show that, compared to old people living with their relatives or partner, those living alone or in a retirement home are in a much worse position. Old people living alone are most often lonely, followed by those living in a retirement home. The role of the family and thus the related importance of relatives was stressed since old people living with their relatives or partner are less lonely. They have relatives around them, while old people living alone or in a retirement home do not. The fact that the family and not just company is important to old people was evident in retirement homes. A lot of old people live there; however, many of them are still lonely. Therefore, we could sum up that relatives are the ones who play an important role. Old people may be surrounded by a lot of people but if they are not the right ones, those they need, this does not minimize their loneliness. Relatives are thus irreplaceable.

Old people living in a retirement home have the least contact with their relatives. It is an interesting fact that old people living alone have frequent contacts with their relatives over the phone and during holidays, however, this does not minimize their loneliness. It is evident that contacts through visits are of key importance since old people living alone do not have them to such extent. Personal family contact plays a key role. 


\section{Acta Technologica Dubnicae \\ volume 5, 2015, issue 1}

To conclude, old people living in a retirement home are the endangered cohort, however, the most endangered includes old people living alone. It is true that old people living in a retirement home have the least contact with their relatives; however, their feeling of loneliness is not as strong as with old people living alone.

Let us consider the following thought: "The world that we are creating today will be enjoyed tomorrow, so it is important to ask ourselves the question, do we want the old age we are offering today for our older?" (Vilfan, 1994, p. 123).

\section{References}

BECK, U. Risikogesellschaft. Auf demWeg ins andere Moderne: Edition Suhrkamp. 2001.

CIJAN, V., and CIJAN, R. Zdravstveni, socialni in pravni vidiki starostnikov. Maribor: Visoka zdravstvena šola, 2003.

HOJNIK ZUPANC, I. Priprava na upokojitev in starost. HOJNIK ZUPANC, I. (ed.) Dodajmo življenje letom: nekaj spoznanj in nasvetov, kako se smiselno in zdravo pripravljati na starost in jo tako tudi živeti. Ljubljana: Gerontološko društvo Slovenije, 1997.

HOJNIK ZUPANC, I. Samostojnost starega človeka v družbeno-prostorskem kontekstu. Ljubljana: Fakulteta za družbene vede, 1999.

HOYMAN, N. R., and ASUMAN, K. Social Gerontology: A Multidisciplinary Perspective. Boston: Pearson, 2009.

HVALIČ TOUZERY, S. Gerontološko izrazje: osamljenost: socialna izolacija. Kakovostna starost, 9, 2006, 4.

KERSNIK BERGANT, M. O starosti in staranju - sociološki pogled. KERSNIK BERGANT, M. (ed.). Naučimo se poslušati: prostovoljno delo starih in za stare. Ljubljana: Slovenska filantropija, Združenje za promocijo prostovoljstva, 1999.

KOLLAND, F. Social Determinants and Potentials of Education in Later Life: The Case of Austria. Educational Gerontology, 19, 1993, 6, pp. 535-550.

KUMP, S., and JELENC-KRAŠOVEC, S. Vseživljenjsko učenje, izobraževanje starejših odraslih. Ljubljana: Pedagoški inštitut, 2009.

LASLETT, P. A Fresh Map of Life: The Emergence of the Third Age. London: Weidenfeld and Nicholson, 1989.

SCOTT, L. M. Measurment and prediction of aging anxiety. Research on Aging. [online]. 22, 2000, 5. [viewed 21 December 2011]. Available from: $<$ http://roa.sagepub.com/content/22/5/533.full.pdf+html $>$

LUANAIGH, C, O. and Lawor, B.A. Loneliness and Health of older people. International Journal of Geriatrics Psychiatry, 23, 2008, 12.

MAGALHAES, DE J. Senescenca na celičnem nivoju. [online]. 2012. [viewed 11 January 2013]. Available from:

$<$ http://www.senescence.info/cell_aging.html $>$

PEČJAK, V. Psihologija staranja. Bled: self-published, 2007. 


\section{Acta Technologica Dubnicae \\ volume 5, 2015, issue 1}

POŽARNIK, H. Umetnost staranja: leta, predsodki in dejstva. Ljubljana: Cankarjeva založba, 1981.

RAMOVŠ, J. Kakovostna starost. Ljubljana: Inštitut Antona Trstenjaka, 2003. RILEY WHITE, M. Aging, Social Change, and the Power of Ideas. American Academy of Arts \&Sciences. [online]. 1978. [viewed 21 January 2012]. Available from: $<$ http://www.jstor.org/discover/10.2307/20024579?uid=2129\&uid $=3739008$ \&uid $=2 \&$ uid $=70 \&$ uid $=4 \&$ sid $=55977744343>$

Statistični urad RS. Umrli, Slovenija, 2012 - končni podatki. [online]. 2013. [viewed 9 September 2013]. Available from:

$<$ http://www.stat.si/novica_prikazi.aspx?id $=5570>$

SVAVAŽIČ, F. Socialni delavec v domu za starejše občane - vez med stanovalci in svojci (Social Worker in the Home for the Elderly - The Link between Residents and Relatives). HOJNIK ZUPANC, I. (ed.) Star človek in družina: učna delavnica, posvečena 25. obletnici Gerontološkega društva Slovenije. Brdo pri Kranju, on 2 and 3 December 1994. Ljubljana: Gerontološko društvo Slovenije, 1994.

TRSTENJAK, A. Človek, bitje prihodnosti. Ljubljana: Slovenska matica, 1985.

VILFAN, B. Socialni delavec na terenu - pomočnik staremu človeku in njegovi družini (Social Worker as an Aide to the Elderly and his Family in their Living Environment). HOJNIK ZUPANC, I. (ed.): Star človek in družina: učna delavnica, posvečena 25. Obletnici Gerontološkega društva Slovenije. Ljubljana: Gerontološko društvo Slovenije, 1994.

Zavod za pokojninsko in invalidsko zavarovanje Sovenije. Starostna pokojnina $v$ letu 2013. [online]. 2013. [viewed 9 September 2013]. Available from:

$<$ http://www.zpiz.si/wps/wcm/connect/zpiz+internet/zpiz/prvastran/uveljavljanje pravic/starostna + pokojnina $+v+$ letu $+2013>$ 